\title{
MENINGKATKAN KEMAMPUAN BERBICARA ANAK MELALUI BERMAIN RODA GAMBAR
}

\author{
Addiniah Sukmawati Wulandari \\ e-mail: wulanaddiniah@yahoo.com \\ PG PAUD Universitas Negeri Jakarta
}

\begin{abstract}
Abstrak: Penelitian ini bertujuan untuk meningkatkan kemampuan berbicara anak usia 6-7 tahun melalui bermain roda gambar. Metode yang digunakan adalah penelitian tindakan yang dilakukan melalui dua siklus, siklus terdiri atas perencanaan (planning), tindakan (acting), pengamatan (observing), dan refleksi (reflecting). Subjek penelitian adalah anak kelas 1 di SDN Rawamangun 15 Pagi, Jakarta Timur yang mempunyai masalah dalam kemampuan berbicara sebanyak 8 orang. Analisis data diperoleh dari hasil perbandingan antara kemampuan berbicara sebelum dan sesudah pelaksanaan tindakan. Hasil akhir dari keseluruhan analisis persentase data adalah ketercapaian hasil sebesar 78.3\%. Berdasarkan persentase ketercapaian hasil dari penelitian ini, maka dapat dinyatakan bahwa hipotesis diterima. Maka dapat disimpulkan bahwa bermain roda gambar dapat meningkatkan kemampuan berbicara anak usia 6-7 tahun. Implikasi hasil penelitian ini adalah bahwa bermain roda gambar dapat dijadikan sebagai alternatif untuk meningkatkan kemampuan berbicara anak usia 6-7 tahun. Peningkatan kemampuan berbicara dapat ditunjukkan melalui produksi kata, penyampaian gagasan, pengajuan pertanyaan, pengekspresian perasaan, serta penyampaian informasi.
\end{abstract}

Kata Kunci : bermain roda gambar, kemampuan berbicara, anak usia 6-7 tahun

\section{IMPROVING SPEAKING SKILLS BY PLAYING A PICTURE WHEEL}

\begin{abstract}
The purpose of this research is to improve speaking skills of children aged 6-7 years by playing a picture wheel in SDN Rawamangun 15 Pagi, Jakarta Timur. This research using action research method that was done by two cycle consisting of planning, acting, observing, and reflecting. The research subject are children aged 6-7 years who had problem in the ability of speaking as many as 8 childrens. The analysis of data was obtained from the comparison between the ability of childrens speaking before and after implemetation of the action. The final result from the overall analysis of data percentage reach to $78,3 \%$. Based on the percentage of end the cycle of this research, so it was stated that the hypothesis can be accepted. Then it can be concluded that playing a picture wheel can improved children speaking ability of aged 6-7 years. The implication of this research is playing a picture wheel can be alternative for improving children speaking ability of aged 6-7 years. The reach of children speaking ability can showed by word producing, conveying the idea, asking the question, expressing emotion, and conveying the information.
\end{abstract}

Keywords: playing a picture wheel, speaking skills children aged 6-7 years.

\section{PENDAHULUAN}

\section{Latar Belakang}

Kehidupan manusia erat kaitannya dengan bahasa. Bahasa memudahkan manusia dalam menjalankan kehidupannya sehari-hari. Bahasa merupakan alat komunikasi yang di gunakan untuk mentransfer pemikiran, ide-ide, dan perasaan kepada orang lain. Bahasa dapat digunakan untuk membuat orang lain mengetahui apa yang sebenarnya ada di benak seseorang, apa yang di inginkan, apa yang di anggap benar atau salah, apa yang di rasakan, dan lainnya.

Masa kanak-kanak adalah masa yang paling tepat untuk mengembangkan bahasa. Karena pada 62 Jurnal IImiah VISI P2TK PAUD NI - Vol. 8, No.1, Juni 2013 masa ini sering disebut masa "golden age" dimana anak sangat peka mendapatkan rangsangan baik yang berkaitan dengan aspek fisik motorik, sosial, emosi maupun bahasa. Rangsangan yang sesuai dengan tahapan usia anak akan membantu anak untuk tumbuh secara optimal dalam setiap aspek perkembangan.

Salah satu aspek dalam berbahasa adalah berbicara. Sejak lahir secara alami manusia akan berkembang menuju arah yang lebih sempurna. Selain perkembangan oralnya, hal lain yang juga menunjang perkembangan berbicara adalah alat pendengaran, Karena dengan alat pendengaran yang berfungsi 
dengan baik maka manusia dapat dengan mudah menerima segala bentuk suara yang di perkenalkan kepadanya. Melalui suara yang di dengar dan dengan kemampuan meniru inilah anak sejak dini akan belajar bagaimana berbicara dan berkomunikasi sesuai dengan perkembangan yang di harapkan.

Berbicara merupakan cara manusia normal untuk berkomunikasi antara sesama manusia sehingga berbicara menjadi suatu hal yang sangat penting dalam kehidupan ini. Berbicara yang dilakukan manusia normal berupa menyatakan pendapat, menyampaikan sesuatu yang dilihatnya, menyampaikan maksud dan pesan, mengungkapkan perasaan dalam segala kondisi emosional dan lain sebagainya. Hal ini juga terjadi pada anak usia 6-7 tahun dimana anak dalam kehidupan sehari-hari setiap anak pasti berbicara dan berinteraksi dengan orang di lingkungan sekitar anak. Anak usia 6-7 tahun berada pada tahapan praoperasional. Pada masa ini kemampuan berbahasa anak berkembang pesat.

Berkembangnya kemampuan berbicara anak usia 6-7 tahun ialah mengetahui perbendaharaan kosa kata sekitar 20.000 hingga 24.000 kata. (Hurclock, 2005:189). Kosa kata yang dimiliki oleh anak usia 6-7 tahun bertambah dengan pesat karena pengalaman baru yang diterima oleh anak. Pengalaman baru yang diterima oleh anak tersebut menciptakan rasa ingin tahu terhadap apa yang dilihatnya sehingga mendorong anak untuk bertanya kepada orang di sekitarnya dengan menggunakan berbagai kosa kata yang dimiliki oleh anak.

Kemampuan berbicara anak usia 6-7 tahun yang sudah mengetahui perbendaharaan kosa kata sekitar 20.000 hingga 24.000 kata terkadang tidak dapat berkembang dengan baik karena sekolah atau lembaga pendidikan pada umumnya menitikberatkan pembelajaran bahasa hanya pada aspek membaca dan menulis. Berbicara mendapatkan perhatian yang minim, padahal pengembangannya sangat penting dilakukan guna meningkatkan potensi diri anak dalam mempelajari segala hal yang berguna bagi dirinya. Kemampuan berbicara yang dimiliki oleh anak, membantu anak dalam mengerti, dimengerti, bertanya, bereskplorasi, berbaur dan menjadi bagian dari lingkungannya.

Bermain dapat dimanfaatkan untuk belajar bahasa. Melalui bermain, anak-anak belajar bagaimana menggunakan bahasa secara nyata dan kontekstual. Bagaimana menggunakan bahasa di waktu marah, di waktu bersedih, atau yang lainnya. Dengan demikian, belajar bahasa melalui bermain akan lebih efektif, karena anak menggunakan bahasa bukan hanya sekadar teoritis, namun praktik dalam kehidupan dan dunia anak sendiri.

Bermain roda gambar melibatkan indera dan tubuh anak dalam memahami aspek bahasa terutama kemampuan berbicara dengan baik. Sesuai dengan yang dinyatakan Sujiono, bahwa beragam gerak dapat merangsang anak agar lebih cerdas sesuai tahapan perkembangannya. (http://kompas.com) oleh karena itu dengan melibatkan indera dan tubuh anak dalam pembelajaran bahasa Indonesia dapat meningkatkan kemampuan berbicara anak. Jadi bermain roda gambar dapat melatih anak menjadi terampil dalam berbicara dengan aktivitas yang menyenangkan.

Dengan demikian berdasarkan hasil observasi yang dilakukan di SDN Rawamangun 15 Pagi, Jakarta Timur dapat dikatakan bahwa kemampuan berbicara anak usia 6-7 tahun dikatakan belum berkembang dengan baik. Anak belum mampu menyebutkan dan menjelaskan tentang sesuatu hal yang dilihatnya. Anak seringkali mendapat kesulitan mengungkapkan pendapatnya ketika pembelajaran berlangsung, bahkan anak masih perlu motivasi dan bantuan dari guru dalam mengungkapkan atau menjelaskan sesuatu. Selain itu tampak dari masih banyak anak yang mengucapkan kalimat yang belum tepat dan jelas seperti "dirumah dulu suka olahraga". Selain itu ketika diberi pertanyaan oleh guru terkait bercerita sesuai dengan pengalaman yang pernah di lakukan oleh anak, anak terlihat kesulitan dalam merangkai kalimat untuk diucapkan.

Berdasarkan beberapa hal yang telah dipaparkan di atas, pembelajaran yang diberikan oleh guru dikelas belum mengasah kemampuan berbicara anak sehingga peneliti perlu memberikan pengalaman langsung yang menyenangkan kepada anak melalui aktivitas bermain roda gambar dengan mengadakan penelitian yang berjudul "Upaya Meningkatkan Kemampuan Berbicara Anak Usia 6-7 Tahun melalui Bermain Roda Gambar di SDN Rawamangun 15 Pagi, Jakarta Timur. Melalui Penelitian Tindakan ini diharapkan peneliti dapat memberikan penyelesaian masalah untuk membantu meningkatkan kemampuan berbicara anak dengan kegiatan bermain roda gambar.

Berdasarkan uraian diatas maka dapat dirumuskan masalah dalam penelitian ini yaitu "Apakah bermain roda gambar dapat meningkatkan kemampuan berbicara pada anak usia 6-7 tahun di SDN Rawamangun 15 Pagi Jakarta Timur?"

\section{Kajian Teori}

\section{a. Kemampuan Berbicara}

Kemampuan yang dimiliki menandakan bahwa seseorang memiliki kesanggupan. Seperti halnya 
yang diungkapkan oleh Wortham (2008:50), kemampuan adalah keterampilan atau kemampuan sebagai kesanggupan dalam bidang tertentu. Berdasarkan definisi mengenai kemampuan di atas, bahwasannya kemampuan itu menunjukkan mampu atau tidaknya seseorang untuk melakukan sesuatu baik dalam bidang pekerjaan ataupun dalam belajar. Misalnya ketika anak diminta untuk mengungkapkan ide atau gagasannya terhadap gambar yang ada pada roda gambar dan mampu memproduksi kata dengan baik secara jelas dan tepat, maka anak tersebut dikatakan mampu. Kesanggupan tersebut terlihat dari apakah seseorang dapat melakukan pada bidang yang digeluti maupun diluar bidangnya.

Kemampuan dalam bidang bahasa mencakup empat aspek, yakni kemampuan menyimak, berbicara, membaca, dan menulis. Keempat kemampuan tersebut saling mempengaruhi. Berbicara merupakan suatu bagian yang tidak terpisahkan dalam kehidupan. Seperti yang dikemukakan oleh Nilsen (2004:132) bahwa "speech is the sound produced to make the words". Dapat diartikan bahwa berbicara merupakan suara yang dihasilkan untuk membuat kata-kata. Dalam hal ini suara merupakan hal penting dalam berbicara. Setiap orang yang berbicara pasti mengeluarkan suara. Suara yang dimaksudkan adalah suara yang dapat menghasilkan suatu perkataan dan tentunya memiliki sebuah arti untuk dipahami.

Berbicara merupakan keterampilan dalam menyampaikan pesan melalui bahwa lisan kepada orang lain. Menurut Lerner, Dkk dalam Jalongo (2007:106) Speech is the expressive form of oral language, speech is a tool form conveying oral language. Berdasarkan pendapat tersebut bahwa berbicara merupakan bentuk ekspresif dari bahasa lisan dan salah satu bentuk alat bahasa lisan yang digunakan untuk menyampaikan pesan atau perasaan kepada orang lain. Ketika seseorang berbicara maka seseorang mengeluarkan bentuk ekspresif dalam menyampaikan pendapat kepada orang lain. Bentuk ekspresif tersebut berupa pesan dan perasaan yang dapat dimengerti.

Penyampaian gagasan maupun ide yang ada di dalam fikiran dapat disampaikan kepada orang lain melalui berbicara. Heroman dan Jones ( 2004:11) mengungkapkan bahwa "through speech, children learn to organize their thoughts and ideas". Melalui berbicara anak dapat mengatur ide-ide dan pemikirannya. Sebelum mengungkapkan sesuatu anak akan berpikir terlebih dahulu tentang sesuatu yang ingin diungkapkan dan selanjutnya hasil dari proses berpikir tersebut disampaikan secara lisan melalui berbicara kepada lawan bicara.
Kemampuan berbicara penting untuk diperhatikan agar komunikasi dengan lawan bicara dapat berjalan secara efektif dan efisien. Semi berpendapat bahwa kemampuan berbicara pada hakikatnya merupakan keterampilan memproduksi sistem bunyi artikulasi untuk menyampaikan kehendak, gagasan, perasaan dan pengalaman kepada orang lain. Berdasarkan pendapat tersebut bahwa kemampuan berbicara adalah kemampuan memproduksi bunyi artikulasi yang digunakan untuk menyampaikan gagasan atau perasaan kepada orang lain.

Nuraeni (2002:87) mengungkapkan bahwa kemampuan berbicara merupakan faktor yang sangat mempengaruhi kemahiran seseorang dalam penyampaian informasi secara lisan. Pendapat tersebut menjelaskan bahwa kemampuan berbicara seseorang cukup berpengaruh pada informasi yang diberikan kepada orang lain. Kemampuan berbicara yang kurang baik dapat menyebabkan kesalahan penyampaian informasi. Hal ini tentu akan berdampak buruk karena memungkinkan timbulnya kerancuan informasi.

Berdasarkan pendapat diatas maka dapat disimpulkan bahwa kemampuan berbicara adalah kesanggupan seseorang untuk menyampaikan pendapat, mengajukan pertanyaan dan mengekspresikan perasaan kepada orang lain. Dalam melakukan hal di atas tersebut, perlu diperhatikan mengenai aspek kebahasaan seperti pengucapan atau artikulasi yang jelas, intonasi yang tepat, pemilihan kata, pengucapan kata yang sistematis dan menunjukkan ekspresi wajah ketika berbicara dengan lawan bicara.

\section{b. Karakteristik Berbicara Anak Usia 6-7 Tahun}

Anak usia 6-7 tahun atau kelas satu sekolah dasar merupakan masa berkembang pesatnya kemampuan mengenal dan menguasai perbendaharaan kata. Setelah anak masuk sekolah, perkembangan jumlah kosa kata sangat mencolok. Hurlock (2005:189) menyatakan bahwa anak kelas satu sekolah dasar yang kira-kira berumur 6-7 tahun, dapat menguasai kosa kata sekitar 20.000 kata, bahkan ada yang sampai 24000 kosa kata. Dengan demikian kosakata anak kelas satu sudah sangat banyak, sehingga anak pada usia ini sudah mampu berkomunikasi dengan orang dewasa.

Pendapat tersebut sejalan dengan Owens dalam Papalia (2008:340) yang menyatakan bahwa pada usia 6 tahun, seorang anak biasanya telah berbicara dengan 2.600 kata dan memahami lebih dari 20.000 kata. Anak berbicara dalam kalimat yang lebih panjang dan kompleks dalam berkomunikasi dengan orang di sekitarnya.

Senada dengan pendapat Jalongo (2007:190) 
yang menyatakan "6-7 years : uses more complex sentences more adjectives; uses "if...... then" conditional clauses; average number of words presentence is 7,6, Vocabulary; speaking vocabulary of about 3.000 words. Artinya bahwa anak umur 6-7 tahun telah menggunakan kalimat yang lebih komplek dengan kata sifat yang lebih banyak, menggunakan klausa kondisional "jika .. maka”, jumlah rata-rata kata-kata perkalimat adalah 7,6 kata dan perbendaharaan kata sekitar 3000 kata.

Berdasarkan pendapat-pendapat yang telah dikemukakan diatas maka dapat disimpulkan bahwa kemampuan berbicara anak usia 6-7 tahun sudah berkembang dengan pesat. Perbendaharaan dan kosakata anakpun bertambah banyak, sehingga memudahkan anak untuk berbicara dan berkomunikasi dengan orang dewasa. Anak pada usia ini sering melakukan percakapan dengan teman sebaya dan lingkungan sekitar. Anak sudah mulai memahami katakata atau kalimat yang rumit, sehingga memudahkan anak untuk berbicara menyampaikan isi, gagasan atau ide kepada orang disekitarnya.

\section{c. Hakikat Bermain Roda Gambar}

Forberg dalam Dockett and Fleer ( 2000:15) yang menyatakan bahwa "play is direct and spontaneous activity by which children engage with people and things arpund them pleasantly, voluntarily, imaginatively, with all their senses, with their hands, or with their whole bodies". Berdasarkan pendapat tersebut, Forberg mengungkapkan bahwa bermain adalah aktivitas spontan dan langsung yang dilakukan oleh anak. Ketika anak-anak bermain, anak akan berinteraksi dengan anak lainnya dan benda-benda yang berada disekitarnya. Anak menggunakan inderanya, tangannya bahkan seluruh tubuhnya untuk bermain dengan rasa bahagia, suka rela atau tanpa paksaan, dan dengan imajinasinya sendiri.

Melihat adanya banyak manfaat bermain bagi anak, ternyata bermain juga merupakan hal yang paling diinginkan oleh anak dalam kehidupannya. Hal tersebut diungkapkan oleh Borstelmann dalam National Asociation Early Young Children (NAEYC) (1995:1) bahwa "children's desire and need to play has been recognize throughout history, but it is not only children who explore and experiment, imagine and play with symbol, and enjoy manipulating the social and physical environment". Dari pemaparan tersebut dinyatakan bahwa anak-anak membutuhkan dan ingin selalu bermain, hal ini telah diakui sepanjang sejarah. Melalui aktivitas bermain anak-anak tidak hanya dapat bereksplorasi dan bereksperimen melainkan membayangkan, bermain dengan simbol, dan memanipulasi lingkungan sosial dan fisiknya. Berdasarkan hal tersebut, dengan kata lain anak-anak sangat membutuhkan porsi bermain lebih banyak dibandingkan apa yang dibayangkan oleh orang dewasa.

Berdasarkan beberapa pendapat yang dimaksud dengan bermain pada penelitian ini adalah merupakan kebutuhan penting bagi anak. Kebutuhan ini disalurkan melalui aktivitas yang langsung dilakukan oleh anak. Dalam bermain anak melibatkan indera bahkan seluruh bagian tubuhnya sehingga dapat membantu seluruh aspek perkembangan anak baik fisik, sosial, dan emosional.

Dalam kegiatan bermain, ada beberapa jenis permainan anak yang sesuai dengan tahapan usianya. Tahapan bermain menurut Smilansky dalam jalongo (2010:48) yaitu, 1). Functional play, 2). Constuctive play, 3). Dramatic play, 4). Game with rules. Keempat tahapan tersebut merupakan tahapan bermain kognitif. Smilansky mengemukakan pendapat tersebut didasarkan pada pengadaptasiannya kepada tahapan perkembangan kognitif Piaget.

Game with rules merupakan tahapan tertinggi dalam tahapan perkembangan bermain. Kegiatan bermain jensi ini umumnya sudah dapat dilakukan anak pada usia 6-11 tahun. Pada usia tersebut anak mulai memahami dan mengikuti peraturan permainan. Semakin lama anak mengerti bahwa ia dapat mengubah peraturan itu sendiri asalkan tidak terlalu jauh menyimpang dari aturan umumnya.

Berdasarkan pendapat diatas, pada usia 6-7 tahun anak berada pada tahapan games with rules. Menurut Pelegrini dan kawan-kawan (2004:116), "elementary school students often engage in games with rules and very infrequently engage in functional and constructive play; dramatic play occurs but infrequently". Pada usia sekolah dasar anak mulai bermain yang menggunakan aturan. Anak mulai bermain bersama teman sebayanya baik secara kelompok maupun tidak. Anak sudah mulai jarang memainkan permainan-permainan pada tahap functional play, constructive play, dan dramatic play.

Games with rules dapat membantu anak dalam membangun hubungan sosial dengan orang lain, khususnya teman sebayanya. Getwiscki (2007:263) mengungkapkan bahwa "one of the primary aged children attempt to regulate their own social relation is by basing their play in games with explicit rules". Permainan pada tahapan ini umumnya dilakukan dengan cara berkelompok. Hal tersebut dapat memungkinkan anak untuk dapat berinteraksi cara bekerja sama dalam kelompok, saling toleransi, dan mentaati peraturan bersama. 
Berdasarkan pemaparan diatas, dapat dilihat bahwa pada usia 6-7 tahun permainan anak yang sesuai dengan rentang usianya ialah games with rules. Terkait dengan pernyataan tersebut, James (1994:26) menyatakan bahwa "it is importance of rules as a way making life easier, rather than something that is imposed by adults of children". Peraturan-peraturan dalam permainan yang dimainkan oleh anak memudahkan anak dalam mentaati peraturan yang dibuat oleh orang dewasa. Dengan adanya peraturan, anak dapat belajar mengenai mentaati peraturan melalui kegiatan bermain.

Berdasarkan pemaparan diatas, dapat dilihat bahwa pada usia 6-7 tahun permainan yang sesuai dengan usianya adalah games with rules. Pada tahapan tersebut, anak mulai dapat menerima aturan dan mulai beradaptasi dengan peraturan. Hal tersebut berarti bahwa pada usia 6-7 tahun anak sudah mengenal dan mengerti dalam kegiatan bermainnya. Anak sudah terbiasa untuk menyesuaikan keinginankeinginan pribadinya dengan keinginan-keinginan orang lain. Alat permainan dalam penelitian ini terkait dengan tahapan bermain games with rules adalah roda gambar. Dalam bermain roda gambar terdapat peraturan-peraturan yang akan dilaksanakan oleh anak ketika mulai bermain.

Bermain roda gambar harus memperhatikan langkah-langkah dalam penggunaan roda gambar yang disesuaikan dengan tahapan bermain pada anak usia 6-7 tahun yakni games with rules. Langkah- langkah bermain roda gambar adalah sebagai berikut (1) Anak diperkenalkan dengan media roda gambar yang digunakan dalam bermain aktif, (2) Mintalah salah satu anak akan memutar roda gambar, setiap anak mendapatkan giliran untuk memutar roda gambar dan dilakukan secara bergantian. (3) Roda akan berhenti secara perlahan, kemudian mintalah anak untuk menjelaskan isi gambar yang ditunjukkan oleh jarum pertunjuk, (4) lakukan lagi di mulai dari memutar roda gambar hingga anak diminta untuk menjelaskan isi dari gambar. Aktivitas menjelaskan isi gambar dilakukan dengan aktivitas bermain yang bervariasi agar anak tidak merasa bosan, menyenangkan, dan melibatkan indera serta tubuh anak.

Berdasarkan pemaparan di atas, bermain roda gambar merupakan salah satu permainan anak usia dini yang dapat digunakan sebagai alat permainan dalam proses pembelajaran. Alat permainan roda gambar merupakan karya inovasi yang dibuat oleh peneliti untuk melakukan penelitian terkait kemampuan berbicara anak usia 6-7 tahun. Bermain roda gambar dalam penelitian ini adalah bermain dengan menggunakan roda yang berbentuk lingkaran yang mempunyai jarum. Tinggi tiang pada roda gambar adalah $120 \mathrm{~cm}$ dan diameter lingkaran $60 \mathrm{~cm}$. Lingkaran tersebut dapat diputar. Apabila jarum berhenti pada gambar tertentu, anak diminta untuk menjelaskan isi dari gambar tersebut. Anak menggerakkan anggota tubuhnya untuk dapat mengikuti alur

\section{METODE PENELITIAN}

Penelitian tindakan ini dilaksanakan pada Maret sampai dengan Juni 2012 di SDN Rawamangun 15 Pagi yang beralamat di Jalan Pemuda No.6 Rawamangun, Jakarta Timur . Penelitian dilakukan di tempat ini dikarenakan peneliti menemukan data terkait masalah pada saat melakukan observasi. Sesuai dengan hasil observasi, dari 21 anak yang berada pada kelas 1 Sekolah Dasar di SDN Rawamangun 15 Pagi, peneliti menemukan 8 anak yang memiliki kemampuan berbicara yang masih minim.

Metode yang digunakan dalam penelitian ini adalah penelitian tindakan (action research) dengan pendekatan kualitatif dan kuantitatif. Penelitian tindakan kelas merupakan penelitian yang berupaya untuk memperbaiki efektifitas dan efisiensi pembelajaran di kelas. Penelitian tindakan yang akan dilakukan adalah bentuk penelitian tindakan kolaboratif dimana penelitian tindakan ini mengupayakan adanya kerjasama yang baik antara peneliti dengan guru kelas, kepala sekolah, dosen pembimbing dan teman sejawat.

Pelaksanaan tindakan ini dilakukan sebanyak lima kali dengan durasi 70 menit. Selama melakukan tindakan, peneliti melakukan pengamatan. Pengamatan ini akan dilakukan sepanjang proses tindakan berlansung melalui kolabolator yang mengisi pedoman observasi dan catatan lapangan serta dokumentasi yang dilakukan oleh peneliti. Selesai perencaan, tindakan dan observasi kemudian penelitian akan memasuki tahap refleksi.

Refleksi dilakukan oleh peneliti bersama dengan kolabolator untuk melakukan pengolahan data pada siklus 2. Pengolahan data ini akan menentukan apakah penelitian dinyatakan berhasil. Apabila tidak berhasil maka penelitian dihentikan hanya pada siklus 2. Jika sudah terjadi peningkatan rata-rata indikator keberhasilan kemampuan berbicara anak menjadi 71 $\%$, maka penelitian dinyatakan berhasil melalui siklus 1 dan siklus 2 . 
Data yang digunakan dalam penelitian tindakan ini adalah data kuantitatif dan kualitatif (Kusnandar, 2008:127-128). Analisis data kuantitatif dilakukan secara terus menerus setiap siklus dengan persentasi kenaikan. Analisis data kualitatif dilakukan dengan cara menganalisis data dari hasil catatan lapangan, catatan wawancara dan catatan dokumentasi selama penelitian. Teknik analisis data yang digunakan bertujuan untuk mengetahui pengaruh pemberian tindakan kegiatan bermain roda gambar terhadap peningkatan kemampuan berbicara anak usia 6-7 tahun.

Analisis data menggunakan analisis sebagaimana yang dikemukakan Miles dan Huberman dalam Sugiyono (2008:337), secara umum analisis data yang dilakukan terdiri dari tiga tahap, yaitu (1) reduksi data, (2) display data, dan (3) kesimpulan, dan refleksi. Reduksi data merupakan proses penyederhanaan yang dilakukan melalui seleksi, pemfokusan, dan pengabstrakan data mentah menjadi informasi bermakna. Paparan display data berkenaan dengan proses penampilan data secara sederhana dalam bentuk paparan naratif, representasi tabular, termasuk dalam format matriks, representasi grafik, dan sebagainya, Sedangkan kesimpulan meliputi proses pengambilan intisari dari sajian data yang telah terorganisir.

Setelah tindakan selesai dilaksanakan, maka hasil pengamatan berupa catatan lapangan dan instrumen penelitian dilanjutkan pada tahap analisis kuantitatif. Kolaborator dan peneliti membuat kesepakatan dengan $71 \%$. Indikator keberhasilan ini sesuai dengan pendapat Milis (2003:101) yang menyatakan bahwa the end-of survey revealed that $71 \%$ of student agreed. Berdasarkan pendapat tersebut maka peneliti bersama dengan kolaborator menetapkan indikator keberhasilan penelitian tindakan ini minimal sebesar $71 \%$. Jika persentase yang diperoleh kurang dari $71 \%$ seperti yang telah disepakati bersama maka penelitian akan dilanjutkan pada siklus selanjutnya.

Adapun analisis data kualitatif menggunakan teori Miles dan Huberman yang menyebutkan bahwa ada tiga langkah pengolahan data kualitatif, yakni reduksi data (data reduction), penyajian data (data display), dan penarikan kesimpulan (conclusion drawing and verification). Reduksi data mengandung pengertian peneliti melakukan pemilihan dan permusatan perhatian untuk penyedehanaan, abstraksi, dan transformasi data kasar yang diperoleh. Dalam penyajian data peneliti mengembangkan sebuah deskripsi informasi tersusun untuk menarik kesimpulan dan pengambilan tindakan. Penyajian data disajikan dalam bentuk narasi. Sedangkan untuk penarikan kesimpulan, peneliti berusaha menarik kesimpulan dan melakukan verifikasi dengan mencari makna setiap gejala yang diperolehnya dari lapangan, mencatat keteraturan dan konfigurasi yang mungkin ada, alur kausalitas dari fenomena dan proporsisi. Analisis data kualitatif berupa pedoman observasi yang dituangkan menjadi catatan lapangan. Teknik analisis data yang dilakukan bertujuan untuk mengetahui apakah bermain roda gambar dapat meningkatkan kemampuan berbicara anak usia 6-7 tahun.

\section{HASIL DAN PEMBAHASAN}

Data penelitian menunjukkan hasil rata-rata persentase kenaikan di siklus 2 pada setiap anak adalah sebesar $23.3 \%$ dan perkembangan kemampuan berbicara anak telah meningkat menjadi $78.3 \%$. Hal ini berarti indikator kemampuan berbicara anak berada dalam tahap berkembang atau konsisten. Berdasarkan hal tersebut, maka peneliti memutuskan untuk tidak melanjutkan tindakan ke siklus berikutnya. Selain itu, peneliti dan kolabolator telah memantau persentase kenaikan yang terjadi pada setiap siklusnya dapat dikatakan signifikan. Untuk itu peneliti dan kolabolator menyepakati untuk berhenti pada siklus 2 . Sesuai target pada siklus 1, apabila kemampuan berbicara anak terus meningkat, maka persentase kenaikan dinyatakan signifikan. Berdasarkan hal tersebut, maka persentase kenaikan dinyatakan signifikan. Berikut data tentang persentase kemampuan berbicara anak pada siklus 1 dan siklus 2 .
Tabel 1. Peningkatan Kemampuan Berbicara Anak Pada Pra intervensi sampai dengan Siklus 2 di SDN Rawamangun 15 Pagi, Jakarta Timur.

\begin{tabular}{|c|c|c|c|c|c|c|}
\hline \multirow{2}{*}{ Subjek } & \multicolumn{3}{|c|}{ Persentase } & \multicolumn{2}{c|}{$\begin{array}{c}\text { Peningkatan } \\
\text { Persentase }\end{array}$} & \multirow{2}{*}{ Ket } \\
\cline { 2 - 6 } & $\begin{array}{c}\text { Prainter- } \\
\text { vensi }\end{array}$ & $\begin{array}{c}\text { Siklus } \\
1\end{array}$ & $\begin{array}{c}\text { Siklus } \\
2\end{array}$ & $\begin{array}{c}\text { Siklus } \\
1\end{array}$ & $\begin{array}{c}\text { Siklus } \\
2\end{array}$ & \\
\hline WD & 36.66 & 53.3 & 78.8 & 16.64 & 25.5 & Meningkat \\
\hline ND & 29.16 & 53 & 77.5 & 23.84 & 24.5 & Meningkat \\
\hline AL & 32.5 & 56 & 79.1 & 23.5 & 23.1 & Meningkat \\
\hline KDR & 38.3 & 54.5 & 78 & 16.2 & 23.5 & Meningkat \\
\hline AR & 35 & 53.8 & 78.8 & 18.8 & 25 & Meningkat \\
\hline NR & 36.66 & 53 & 78.3 & 16.34 & 25.3 & Meningkat \\
\hline AN & 35 & 58 & 78.3 & 23 & 20.3 & Meningkat \\
\hline AJ & 33.33 & 55 & 77.6 & 21.67 & 22.6 & Meningkat \\
\hline $\begin{array}{c}\text { Rata- } \\
\text { rata }\end{array}$ & 34.4 & 55 & 78.3 & 20.6 & 23.3 & \\
\hline
\end{tabular}

Berdasarkan tabel di atas, dapat dideskripsikan bahwa rata-rata persentase kenaikan di siklus 2 pada 
setiap anak adalah sebesar $23.3 \%$ dan perkembangan kemampuan berbicara anak telah meningkat menjadi $78.3 \%$. Hal ini berarti indikator kemampuan berbicara anak berada dalam tahap berkembang atau konsisten. Berdasarkan hal tersebut, maka peneliti memutuskan untuk tidak melanjutkan tindakan ke siklus berikutnya. Selain itu, peneliti dan kolabolator telah memantau persentase kenaikan yang terjadi pada setiap siklusnya dapat dikatakan signifikan. Untuk itu peneliti dan kolabolator menyepakati untuk berhenti pada siklus 2 . Sesuai target pada siklus 1, apabila kemampuan berbicara anak terus meningkat, maka persentase kenaikan dinyatakan signifikan. Berdasarkan hal tersebut, maka persentase kenaikan dinyatakan signifikan.

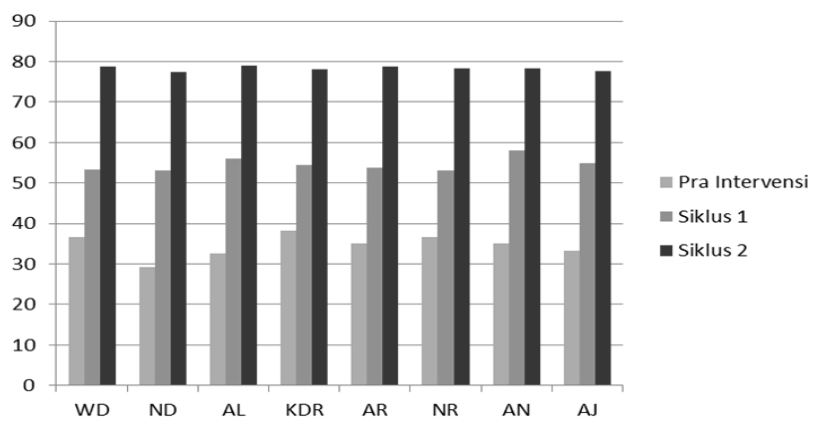

Gambar 1. Grafik Peningkatan Kemampuan Berbicara Anak Usia 6-7 Tahun

Berdasarkan grafik tersebut dapat dilihat bahwa kemampuan berbicara anak pada masing-masing subjek mengalami perubahan. Peningkatan masingmasing responden dari pra intervensi sampai dengan siklus 2 mengalami perubahan yang meningkat. Berdasarkan grafik diatas rata-rata kemampuan berbicara anak meningkat menjadi $78.3 \%$, hal ini juga dapat diartikan bahwa kemampuan berbicara anak meningkat dalam hal produksi kata, penyampaian gagasan, pengekspresian bahasa, pengajuan pertanyaan dan penyampaian informasi.

Hasil analisis data kualitatif membuktikan bahwa bermain roda gambar dapat meningkatkan kemampuan berbicara anak. Aspek pertama yaitu, anak mulai memproduksi kata-kata dengan tepat dan jelas, aspek ini diperkuat oleh Nilsen yang menyatakan bahwa berbicara merupakan suara yang dihasilkan untuk membuat kata-kata dengan tepat dan jelas. Aspek kedua; anak dapat menyatakan pemikiran mereka melalui penyampaian gagasan maupun ide yang dimilikinya. Aspek ini diperkuat oleh Semi yang menyatakan bahwa berbicara merupakan kemampuan memproduksi sistem bunyi artikulasi untuk menyampaikan kehendak, gagasan dan pengalaman kepada orang lain. Aspek ketiga; anak mampu mengekspresikan perasaan yang dirasakan. Aspek ini diperkuat oleh Semi yang menyatakan bahwa berbicara merupakan kemampuan memproduksi sistem bunyi artikulasi untuk menyampaikan perasaan kepada orang lain. Aspek keempat; anak mampu mengajukan pertanyaan. Aspek ini diperkuat oleh Rice dalam papalia yang menyatakan bahwa komunikasi terjalin bagaimana cara anak menanyakan sesuatu kepada orang lain dan Aspek kelima; anak mampu menyampaikan informasi. Aspek ini diperkuat oleh Nuraeni yang menyatakan bahwa kemampuan berbicara merupakan faktor yang sangat mempengaruhi kemahiran seseorang dalam penyampaian informasi secara lisan. Kelima aspek tersebut dinyatakan signifikan karna terjadi peningkatan secara terus menerus saat penelitian.

\section{PENUTUP}

\section{Kesimpulan}

Berdasarkan hasil penelitian, data tersebut dapat dikatakan bahwa persentase dari Pra intervensi ke siklus 1 mengalami peningkatan pada indikator secara keseluruhan sebesar $20.6 \%$. Sebagaimana disampaikan pada interpretasi hasil analisis bahwa penelitian ini dikatakan berhasil jika adanya peningkatan minimal sebesar $71 \%$, maka pada penelitian siklus 1 ini belum dapat dikatakan berhasil karena persentase kenaikan yang didapat sebesar 20.6\% untuk seluruh indikator.

Berdasarkan hasil siklus 2, aspek tertinggi yang dicapai oleh anak ialah aspek produksi kata penyampaian gagasan dan pengekspresian bahasa. Rata-rata anak mengalami peningkatan persentase kemampuan berbicara sebesar $43.9 \%$ dan persentase peningkatan kemampuan berbicara sebesar $78.3 \%$.
Ketiga aspek tersebut paling sering muncul dibanding kedua aspek lain, yakni aspek pengajuan pertanyaan dan penyampaian informasi.

Dari data tersebut dapat dikatakan bahwa persentase siklus 1 ke siklus 2 mengalami peningkatan pada indikator secara keseluruhan sebesar $23.3 \%$. Hal tersebut menunjukkan bahwa persentase kenaikan kemampuan berbicara anak dapat dikatakan signifikan karena terus meningkat. Setelah memperoleh persentase dengan kenaikan yang signifikan, maka penelitian dihentikan. Berdasarkan pemaparan tersebut, maka dapat disimpulkan bahwa pemberian tindakan berupa bermain roda gambar dapat meningkatkan kemampuan berbicara anak usia 6-7 tahun di SDN Rawamangun 15 Pagi, Jakarta Timur.

Berdasarkan data kualitatif, terlihat adanya peningkatan kemampuan berbicara anak usia 6-7 tahun 
melalui bermain roda gambar. Bermain roda gambar dengan interaksi yang variatif serta dengan menggunakan tema dan beberapa materi mampu menstimulasi anak untuk mengembangkan kemampuan berbicara. Bermain roda gambar dapat memunculkan interaksi yang mampu membuat anak terlibat aktif dalam proses pembelajaran. Berdasarkan hasil observasi dalam bentuk catatan lapangan, catatan dokumentasi, dan catatan wawancara dapat dilihat bahwa bermain roda gambar dapat meningkatkan kemampuan berbicara anak usia 6-7 tahun di SDN Rawamangun 15 Pagi, Jakarta timur.

\section{Saran}

Penelitian ini memberikan saran sebagai berikut, yaitu : (1) Jurusan PG PAUD, bermain roda gambar dapat menjadi altermnatif kegiatan belajar dlam meningkatkan kemampuan berbicara pada anak dengan suasan yang menyenangkan. Diharapkan jurusan dapat menyebarkannya ke sekolah-sekolah sehingga pembelajaran di sekolah lebih bervariasi dan bermakna. Kemampuan berbicara pada anak usia 6-7 tahun dapat meningkat melalui bermain roda gambar; (2) untuk Guru, bermain roda gambar untuk meningkatkan kemampuan dapart menjadi bahan yang menarik bagi anak. Guru dapat memberikan pembelajaran melalui bermain roda gambar yang dilakukan dengan suasana menyenangkan, sehingga pembelajaran yang diberikan tidak hanya berkisar kegiatan membaca dan menulis; (3) untuk Orangtua, para Orangtua dapat menyadari bahwa sebenarnya aspek berbicara merupakan aspek bahasa yang penting untuk dipelajari oleh anak. Orangtua dapat memberikan pengetahuan kepada anak melalui kegiana bermain roda gambar dengan roda gambar sederhana yang dirancang sendiri; dan (4) untuk Peneliti selanjutnya, dapat melakukan penelitian yang berkaitan dengan aktivitas pembelajaran yang dapat dilakukan melalui bermain roda gambar yang berkaitan dengan berbagai aspek perkembangan lainnnya, terutama pada anak usia dini.

\section{DAFTAR PUSTAKA}

Bronson, Martha B, 1995, The Right Stuff for Children Birth to 8. Washington DC : NAEYS.

Cate, Heroman dan Candy Jones,2004, Literacy: The Creative Curriculum Approach. Washington DC: Teaching Strategies Inc.

D.Angelo Bromley, Karen, 1992, Language Arts Exploring Connection.Boston Allyn and Bacon.

Getwiscki, Carol,2007, Development Appropriate Practice. New York: Thomson

Hurlock, Elizabeth B, 2005, Perkembangan Anak Jilid 1. Jakarta : Erlangga

Isenberg, Joan Packer dan Mary Renck Jalongo, 2010, Creative Thinking and Arts-Based Learning Preschool Through Fourth Grade Fifth Edition. New Jersey: Pearson.

Jalongo, Mary Renck, 2007, Early Childhood Language Arts, fourth edition. America : pearson education, inc.

James, Frances and Ken Browndsound, 1994, A Possitive Approach. England: Belair

Kompas, Rabu, 6 Januari 2010, Anak lelaki Lambat Berbicara.

Malla, M. Akil, 2002, Fungsi Strategis Sarana Pembelajaran dalam pendidikan Anak usia Dini, Buletin PADU : Jurnal ilmiah Anak Usia Dini. Jakarta Direktorat PADU.

Mangkunegara, Kevin Davis, 2000, Psikologi Pendidikan. Jakarta: Rineka Cipta.

Milis, Geoffrey E, 2003 Action Research: A Guide For Teacher Research. New Jersey: Pearson

\section{Education}

Munandar, SC. Utami, 2008, Mengembangkan Bakat dan Kreativitas Anak Sekolah. Jakarta : Grasindo

Nilsen, Ann Barbara, 2004, Week by week. United States of America: Thomson Delmar Learning.

Papalia, Diane E.,et.al.,2008, Human Development (Psikologi Perkembangan) Edisi Kesembilan. Jakarta: Kencana Prenada Media Group.

Santrock, John W, 2002, Life-span Development (Perkembangan Masa Hidup) Edisi kelima. Jakarta: Erlangga.

Semi, M. Atar, Rancangan Pengajaran Bahasa dan Sastra Indonesia

Soe, Dockett \& Marilyn Fleed, 2000, Play and Pedagogy in Early Childhood. Australia : Harcout, 2000.

Sudijono, Anas, 2003, Pengantar Evaluasi Pendidikan. Jakarta: PT. Raja Grafindo Persada.

Sugiono, 2008, Metode Penelitian Pendidikan Pendekatan Kuantitatif, Kualitatif R\&D. Bandung: Alfabeta.

Tedjasaputra, Mayke S, 2001, Bermain Mainan dan Permainan. Jakarta : Grasindo

Wortham, Sue.C ,2008, Assesment in Early Childhood Education Fifth Edition. Ohaio : Pearson

Juanda, Dadan , http://jurnal.upi.edu/mimbar-pendidikan/view/372/belajar-bahasa-indonesia-sambilbermain.html

Sujiono, Bambang, 2010, Ragam Stimulasi Gerak Biar Anak Cerdas (http://kompas.com) 